\title{
Mathematics Constructivism with Islamic Values Based on Independence of Student's Learning
}

\author{
Nila Ubaidah ${ }^{1}$, Hevy Risqy Maharani ${ }^{2}$, Anggar Titis Prayitno ${ }^{3}$ \\ Math Education, Universitas Islam Sultan Agung, Semarang, Indonesia ${ }^{1,2}$, \\ Math Education, Universitas Kuningan, Jakarta, Indonesia ${ }^{3}$ \\ \{nilaubaidah@unissula.ac.id ${ }^{1}$,hevyrisqi@unissula.ac.id², anggar.titis.prayitno@uniku.ac.id ${ }^{3}$ \}
}

\begin{abstract}
This study aims to describe how the level of mathematical understanding of students in completing the line and angle material in terms of student learning independence through Islamic Value-Based Constructivism Mathematics at SMP Negeri 1 Rowosari Kendal. This research is a descriptive qualitative research with a case study approach. The data collection methods used tests, questionnaires, and documentation. Data analysis was carried out starting from data reduction, data presentation, and drawing conclusions. The results show: a) computational understanding skills $82.50 \%$. b) Functional understanding skills $85.13 \%$.. The results of interviews with students showed that there were some students who stated that they were still confused when they encountered questions that were different from the examples, but some students had no difficulty in solving the test questions given by the researcher.
\end{abstract}

Keywords: constructivism, Islamic value, Independence of student's learning.

\section{Introduction}

Education for each discipline in addition to helping students think, also helps students be accountable for their thinking. Mathematics education deserves this responsibility because mathematics from elementary to higher education can be used to solve problems [1]. Mathematics as a basic science studied at every level of education has a function, namely as a tool, mindset, and knowledge. Mathematics is creativity that requires imagination, intuition and discovery. The implications of this view for learning mathematics are encouraging initiative and giving opportunities to think differently, encouraging curiosity, the desire to ask questions, the ability to argue and the ability to predict, rewarding unexpected findings as useful, encouraging students to discover mathematical structures and designs, encouraging students value the discoveries of other students, and encourage students to think reflexively.

In the learning process there is a cognitive component to each affective goal and conversely there is an affective component to each cognitive goal. The affective aspect can influence the cognitive aspect, so it is impossible to separate the cognitive domain from the affective domain in a lesson. With the implementation of 2013 curriculum, it has encouraged teachers to integrate affective and cognitive domains in learning. The affective domain component in this study is reviewed from the mathematical disposition of students [2]. 
Everyone who studies mathematics will have math skills. Mathematical proficiency can be possessed by someone who has studied it. This skill consists of five components, namely: 1) Conceptual Understanding; 2) Smooth Procedure (Procedural Fluency); 3) Strategic Competence; 4) Adaptive Reasoning (Adaptive Reasoning); and 5) Productive Disposition [3].

Mathematical understanding is one of the goals of any material presented by the teacher, because the teacher is a student guide to achieve the expected concept [4]. In line with what [5] argues, mathematical understanding is the goal of a mathematics learning process. Mathematical understanding as a goal, means an ability to understand concepts, distinguish a number of mutually exclusive concepts, and the ability to make meaningful calculations on a wider problem situation or problem. So that the ability to understand mathematics is a strength that must be considered and treated functionally in the process and objectives of learning mathematics [6].

Scholtz [2] has argued that mathematical understanding is the cognitive behavior of students which includes conceptual knowledge and procedural knowledge. Students not only know the concept, but students must also be able to use their knowledge in calculations. [7] "Scholtz [2] has argued that mathematical understanding is a basic ability that every student must have". Having a mathematical understanding by students will make it easier to learn and solve math problems and even math problems in the real world [8] then [9] also explained that mathematical understanding is the basis for thinking and solving mathematical problems in everyday life.

Adab is an order or values that govern actions of decency based on religious rules. In a religious teaching, adabs are very important and upheld. In fact, in Islam adab has its own rules and places such as adabs towards God, adabs for humans, adabs in daily actions. One of them is about adab in studying. In studying adab, it plays an important role as well as a quote in a book that "study adab before studying science". That studying is an obligation for Muslims. However, above these obligations there are still requirements that need to be carried out, namely studying an adab. In realizing knowledge, it does not only come, sit down then listen to the teacher's explanation but also how students can implement everything that is learned in everyday life in the community either with their peers or older than them. In this increasingly untouched digital era, there is a need for a diminishing awareness of adab. For this reason, adab plays an important role in education in order to foster civilized souls, one of which is by including Islamic literacy in the learning system. Islamic literacy is a learning that contains elements of Islamic education in it. In this case it does not mean reducing existing learning. However, Islamic literacy is applied so that students know and understand more about Islam and other things that need to be done and don't have to be done related to their religion. The integration of Islamic values is in line with the independence of student learning and constructivism learning, in QS. Yunus Verse 101, which states that there are at least 4 points of way of developing student learning independence, namely 1) Introducing students to the surrounding environment; 2) Build or construct students' understanding or knowledge; 3) Give students the freedom to determine and construct their own knowledge; 4) giving students the freedom to determine their own learning methods.

Learning independence has a relationship with the level of students' mathematical understanding because in addition to cognitive aspects there are affective aspects that can contribute to the success of learning mathematics, one of which is student learning independence. If students have an independent learning attitude, both inside and outside the learning process, students will easily digest the lessons that have been delivered by the teacher or students will easily digest the lessons learned, so that students can easily apply their ideas to solve problems, face or solve problems they get from the teacher. Success in learning should 
not only rely on face-to-face activities and structured assignments given by the teacher, but lies in the student's learning independence [10].

An example of a form of independent student learning is learning before the material is taught by the teacher. This can increase the level of students' mathematical understanding. Students can ask the teacher when learning mathematics is taking place, what is not understood, then students can repeat it independently after completing mathematics learning, so that the level of student understanding of the material will be even better [11]. One alternative that can be used is the use of constructivism mathematics learning with Islamic values based on student learning independence which emphasizes that knowledge is actively built by students themselves based on the knowledge they have. This study aims to describe Mathematical Constructivism learning with Islamic values based on Student Learning Independence at SMP Negeri 1 Rowosari at Kendal district.

\section{Research Methods}

The research method used in this research is descriptive qualitative. The research subjects were students of SMP Negeri 1 Rowosari in Kendal District, class VIII. Purposive sampling (surposive sampling). Research procedures include: (1) the pre-field stage, (2) the stage of field work, and (3) the stage of data analysis. Data collection techniques obtained from the field in the form of tests, questionnaires, interviews, and documentation. Meanwhile, structured questionnaires and interviews were used to obtain data about the independent learning of grade VIII students during the teaching and learning process. At the time of observation, researchers used observation sheets that had been prepared and structured interviews aimed at students and teachers.

The instruments used by researchers to collect data were tests, questionnaires and interviews. The test questions are used to test the level of understanding of students' mathematics using the mathematical constructivism method with Islamic values. While this questionnaire is used to test students' learning independence. The validity strategy of data analysis used in this descriptive qualitative research is ethnography. While the data analysis technique used is data reduction, there are 3 techniques in data reduction namely choosing the main things, presenting data in the form of narrative text and drawing conclusions or verification. To prove that the data is considered reliable and valid, triangulation techniques need to be proven. The examination technique used in this study is the method triangulation, which is to obtain a level of confidence by checking the data collection technique or the data source.

\section{Results and Discussion}

Based on the results of the study, both NL-1 and NL-2 subjects had a level of mathematical understanding in the "Very Understood" category. There is no significant difference with respect to indicators of mathematical understanding. This means that the NL-1 and NL-2 subjects are able to classify objects based on whether or not the requirements for the concept of lines and angles are met, able to explain verbally in their own language about the concepts of lines and angles, able to connect concepts with procedures, able to apply concepts in calculations, able to provide examples and not examples of the concept of lines and angles, have not been able to solve problems of lines and angles in various ways and have not been 
able to develop the concept of lines and angles into spaces. There is only a slight difference in working on problem number, the NL-1 subject in working on problem number 2 by applying the concept of opposite corner relations, while the NL-2 subject in working on problem number 2 applies the concept of opposite angle and opposite angle relations. In addition, in working on problem number 3, subject NL-1 mentions examples of objects that form right angles are blackboards, calendars, photos and not examples of objects that form right angles are circular wall clocks, circular trash cans, lamps . Meanwhile, subject NL-2 mentions examples of objects that form right angles are doors, banners, flags and not examples of objects that form right angles are circular wall clocks, circular trash cans, flower pots. As well as working on problem number 4, the NL-1 subject did it in one way correctly, while the NL-2 subject did it in two ways, but there was an error in one way.

Furthermore, both ST-1 and ST-2 subjects have a level of mathematical understanding in the "Sufficiently Understood" category. There is no significant difference with respect to indicators of mathematical understanding. This means that subjects ST-1 and ST-2 are able to classify objects based on whether or not the requirements for the concept of lines and angles are met, able to explain verbally in their own language about the concepts of lines and angles, able to connect concepts to procedures, able to apply concepts in calculations, able to provide examples and not examples of the concept of lines and angles, have not been able to solve problems of lines and angles in various ways, and have not been able to develop the concept of lines and angles into space. There was only a slight difference in working on the problem, the ST-1 subject worked on question number 2 by applying the concept of the corner-to-face relationship, while the ST-2 subject worked on problem number 2 by applying the concept of the opposite corner relationship. In addition, in working on problem number 3, subject ST-1 mentions examples of objects that form right angles are rulers, fences and mentions that are not examples of objects that form right angles are bicycle wheels, triangular rulers, raffia (straight ). . While the ST-2 subject mentions examples of objects that form right angles are square pillows, laptops, tvs and not examples of objects that form right angles are balls, bolsters, and circular plates. And in working on question number 4, subject ST-1 did not do it at all while subject ST-2 did it in one way but there were still errors.

Then between the BY-1 and BY-2 subjects, both of them had a level of mathematical understanding in the "Poor Understanding" category. There is no significant difference with respect to indicators of mathematical understanding. This means that the BY-1 and BY-2 subjects have not been able to classify objects based on whether or not the requirements for the concept of lines and angles have been met, have not been able to explain verbally in their own language about the concepts of lines and angles, have not been able to connect concepts with procedures, have not been able to apply the concept of calculation, has not been able to provide examples and not examples of the concept of lines and angles, has not been able to solve problems of lines and angles in various ways, and has not been able to develop the concept of lines and angles into spaces. There was only a slight difference in working on the problem, the BY-1 subject worked on question number 3 only gave examples of objects that formed right angles, namely the blackboard, cupboard, cellphone. Meanwhile, the BY-2 subject only drew examples of objects that form right angles without mentioning the name of the object in each image. In addition, there is a difference in working on problem 5, the BY-1 subject is working on problem number 5 entirely incorrectly, while the BY-2 subject works on problem number 5 with a little that is correct, namely parallel line pairs: $\mathrm{HG} / / \mathrm{EF} / / \mathrm{AB} / / \mathrm{DC}$; $\mathrm{HD} / / \mathrm{EA} / / \mathrm{GC} / / \mathrm{FB} ; \mathrm{AD} / / \mathrm{BC} / / \mathrm{FC} / / \mathrm{EH}$. 


\section{Conclussion}

Based on the discussion it can be concluded that:

a) Subjects with Very Independent Learning (NL) both have a level of mathematical understanding "Very Understood". That means; Subjects with independence Very Independent able to classify objects based on whether or not the requirements for the concept of lines and angles are met, able to explain verbally in their own language about the concepts of lines and angles, able to connect concepts with procedures, able to apply concepts in calculations, able to provide examples and not an example of the concept of lines and angles, have not been able to solve problems of lines and angles in various ways and have not been able to develop the concept of lines and angles into spaces.

b) Subjects with Self Sufficiently Independent learning (ST) both have a level of mathematical understanding of "Sufficiently Understood". That means; Subjects with self-reliance Sufficiently Independent able to classify objects based on whether or not the requirements for the concept of lines and angles are met, able to explain verbally in their own language regarding the concepts of lines and angles, able to connect concepts to procedures, able to apply concepts in calculations, able to provide examples and not an example of the concept of lines and angles, have not been able to solve problems of lines and angles in various ways, and have not been able to develop the concept of lines and angles into spaces.

c) Subjects with less independent learning independence (BY) both have a level of mathematical understanding of "lack of understanding". That means; Subjects with independence Lack of independence have not been able to classify objects based on whether or not the requirements for the concept of lines and angles have been met, have not been able to explain verbally in their own language regarding the concepts of lines and angles, have not been able to connect concepts with procedures, have not been able to apply concepts in calculations, has not been able to provide examples and not examples of the concept of lines and angles, has not been able to solve problems of lines and angles in various ways, and has not been able to develop the concept of lines and angles into space.

\section{References}

[1] Hudojo : Mathematics Teaching and Learning Strategies. IKIP Malang (2005)

[2] Depdiknas: An Analysis of students' mathematical reasoning ability (2006)

[3] Kilpatrick, et.al : Effects of population reduction on home ranges of female whitetailed deer at high densities pp : 116 (2001)

[4] Bani, Asmar : Improving Junior High School Students' Mathematical Understanding and Reasoning Ability through Guided Invention Learning, Sps Upi, Bandung. " Journal of Educational Research (2011) Muliyanty, Hanifah, and Sugandi (2018)

[5] Syarifah : Analysis of Mathematical Comprehension Ability in Mathematics Learning Subjects in Senior High School. " Journal of Mathematics Research and Learning 10 (2) pp. 57-71 (2017)

[6] Mulyati : Increasing the Ability of High School Students' Mathematical Understanding and Representation through PQ4R Strategy. " Journal of Mathematics Education Study Program Analysis, UIN Sunan Gunung Djati Bandung (2016) 
[7] Sarwoedi : The Effectiveness of Ethnomatematics in Improving Students' Mathematical Comprehension Ability. Introduction to Ethnomatematics Understanding. " Raflesia Journal of Mathematics Education 03 (02) pp. 101-6 (2018)

[8] Effendi : Concept Understanding of Class Viii Students on Cube and Block Material. " Symmetry: Pasundan Journal of Research in Mathematics Learning and Education 2 (4) pp. 87-94 (2017)

[9] Lambertus : Developing Skills Understanding of Mathematical.” International Journal of Education and Research 4(7) pp. 315-26 (2016)

[10] Muliyanty, H R, A N Hanifah, and A I Sugandi : The Relationship Between Mathematical Comprehension Ability With Junior High School Students Learning Independence Using Contextual Approach. " Journal of Innovative Mathematics Learning 1 (6) (2018)

[11] Putra et al. : Mathematical Comprehension Ability of Junior High School Students in West Bandung. " Journal of Mathematics Research and Learning 11 (1) (2018) 